\title{
DIALECTOLOGICAL PECULIARITIES OF THE KAZAKH LANGUAGE OF KUNGRAD REGION IN KARAKALPAKSTAN
}

\author{
Iristi Kuttimuratova ${ }^{1}$ \\ ${ }^{1}$ Doctor of Philosophy in Philological Sciences, Nukus state pedagogical institute named \\ after Ajiniyaz, \\ Gaukhar Bazarbaeva ${ }^{2}$ \\ ${ }^{2}$ Magistrant Nukus state pedagogical institute named after Ajiniyaz, Nukus, Karakalpakstan
}

Article DOI: https://doi.org/10.36713/epra4584

\begin{abstract}
The given paper devoted to the study of the Kazakh dialectology, phonetic, lexical and grammatical peculiarities of the Kazakh language spoken in Karakalpakstan, The main aim of our work is to study the Kazakh language of the people living in Kungrad region of Karakalpakstan. There have been many changes in the Kazakh language under study because of the influence of mass media, radio, television and different classes at schools in the regionKazakh, Uzbek, Karakalpak and Turkmenian.

KEY-WORDS: dialect, lingua-geography, aspect, linguistics, comparatively-historical grammar of the language, history of the language, inner structure of the language, Kazakh dialectology, monographic research, dialectological atlas of the Kazakh language, dialectological dictionary, Kazakh linguistics, dialectological phenomena.
\end{abstract}

\section{DISCUSSION}

In most languages dialectology is considered to be a separate branch of a science that deals with ethnography. In modern Linguistics dialectology is a science of studying the dialects of a certain national language. It promotes to the development and enrichment of Linguistics. According to some researches, it is divided into two groups:

1. The descriptive dialectology

2. The historical dialectology

The descriptive dialectology deals with phonetic, lexical and grammatical structure of the dialects in the language. The historical dialectology studies the origin and historical aspects and peculiarities of dialects. The existence and appearance of dialects on certain territories depend on different factors. One and the same dialect may include various word-stocks $[3,46]$.
The dialectal words used on a certain territory have their isoglosses. There is difference between the terms dialectal words and dialectisms. Dialectal words are those words which in the process of integration of the national language remains beyond its literary boundaries, and their use is generally confined to a definite locality. Dialectal words are words used on a certain territory that differ from the literary language in phonetics, vocabulary and grammar, the dialectisms are words used only in spoken language. It was obvious that from the earliest time the languages were divided into dialects. In the grammar of that period there were such terms as вульгаризм (vulgarism) - slang word, провинциализм - localisms were one of the main bases of forming the dialectology. There is sometimes a difficulty in distinguishing dialectal words from colloquial words. The term dialect has no 


\section{SJIF Impact Factor: 7.001| ISI I.F.Value:1.241| Journal DOI: 10.36713/epra2016 \\ ISSN: 2455-7838(Online) EPRA International Journal of Research and Development (IJRD)}

Volume: 5 | Issue: 6 | June 2020

- Peer Reviewed Journal

designations in the languages, it defines the wordstock of a certain territory. The dialect is a part of the public national language, it has broader meaning than the term word-stock. All of them are based on the varieties of the language. The word-stock has the status of a dialect when it possesses the norms of the literary national language on the one hand, and when it has some peculiarities and difference from other dialects, on the other hand.

The words from dialects and word-stock of small groups enter the literary language. These words are widely used by people and are accepted as a norm of the literary language. The literary language has its distinguishing features. The modern Kazakh language has its phonetic and lexical-grammar norms. Each of these varieties serves for people of certain speciality or profession. Therefore the literary language relies on the spoken language, the latter serves to the literary language. It is the language used in everyday life, the language with its norm and used as a means of communication $[4,90]$.

The northern and southern dialects play a great role in the development of the Kazakh literary language. The vocabulary of the literary language is based on the vocabulary of the spoken language. Literary and spoken languages can't be considered two separate languages, they are two varieties of the same language having the distinguishing features.

The distinguishing features of the Kazakh language of the people living in different regions are connected with historical factors. For example, the dialectological peculiarities of the Kazakh language of the people living in Karakalpakstan can be explained by the influence of the Karakalpak language, and the languages of the neighbouring Uzbek and Turkmenian people. A lot of words from the above-mentioned languages have entered the Kazakh language for ages, they became the part of the vocabulary stock of the Kazakh language [5].

The research of the Kazakh language of the people living in Kungrad region of Karakalpakstan is very important and deserves attention. The language, traditions, customs of the Kazakh people living in Kazakhstan and Karakalpakstan are their wealth and cultural heritage left by off-springs from the ancient times. The language of the Kazakh people of this region has some peculiarities and it differs from the literary Kazakh language and its dialects. There are some reasons of it. Firstly, the Kazakhs of Kungrad region and of the Republic of Kazakhstan live far away from each other. Secondly, the Kazakh people living in this region, have close cultural relations with the people of Uzbek, Karakalpak and Turkmenian nationalities. Thirdly, the number of Kazakhs living in this region is less than the number of Uzbek, Karakalpak and Turkmenian people.
The vocabulary stock of the Kazakh language in Kungrad region has some elements of the Uzbek, Karakalpak, Turkmenian, Arabian, Persian and Tadjik languages. The first President of the Republic of Uzbekistan I.A.Karimov said, «We are the people born and living in great Turan. Both- our language and religion are the same» [1: 19]. Really, having analyzed the material, we come to the conclusion, that the Uzbek, Karakalpak and Turkmenian languages made a great influence on the Kazakh language of Kungrad region.

The detailed analysis of the Kazakh language of the people living in the collective farms «Raushan» and «Kokdarya» shows the distinguishing features and difference of this language from the Kazakh language spoken in other regions of the Republic of Karakalpakstan and other republics.

The comparative study of the material shows that many dialectal words coincide with the words in the vocabulary of the people living in the south part of Karakalpakstan. Dialectal words include historical words and borrowings from other languages, and it should be pointed out, that most of them was borrowed from Karakalpak. The abundance of the elements of the Karakalpak language shows its influence on the vocabulary stock. The comparative study of the phonetic system in other regions shows that they have some differences in the system of vowels and consonants. According to the statements of the scholar, the grammar of the Kazakh language of the people living in Karakalpakstan is considered to be literary it is not separated from other wordstock groups. It was emphasized that some verbforming suffixes like $-\mathrm{H} /-\mathbf{b} /-\mathbf{i н},-$-сыңыз/-сіңіз, жақ, -сан/-сен are considered to be the dialectal grammar phenomena. One of the distinctive grammar features in the Kazakh language of the people living in Karakalpakstan is the use of Past tense. In the lexical material such words as ағза-member, мәдени шертек-half-house, аударыспақrevolution, сүзеуік-а means used for pouring dish, шөлкем-an organization are used in the literary language.

B.Beketov studied the phonetic, lexical and grammatical peculiarities in the Kazakh language of the people living in the South regions of Karakalpakstan (Turtkul, Beruniy and Amudarya) $[2]$.

For example, at the beginning of words instead of the sound $\boldsymbol{\sigma}$ in the literary language the sound $\boldsymbol{n}$ is used: пал-бал-honey, пұтақ-бұтақ-а kind of grass, instead of the sounds $\kappa, \kappa$ the sounds $F$, 2 are used: ғажырлы-қажырлы, ғарғыс-қарғыс, гейде-кейде-sometimes, гүрес-күрес-wrestling-a kind of sport, чекпен-шекпен-clothes, кепчіккөпшік-pillow, үч-үш-three, бірінчі-биринши-first. 
We observe the use of one sound instead of the other in words, for example: $c-u, ж-\partial ж, ж-\breve{~ б е ш-б е c-~}$ five, тұрмыш-тұрмыс-family, джақсы-жақсыgood, йыл-жыл-year, йаңа-жаңа- a nеw [6].

In grammar the following suffixes: -dap/дер, -тар/-тер, -лар/-лер show the plural form nouns. There are differences in the cardinal numerals as well. For example: (сексен сегіз бүтін жүзден бес, сексен сегіздің жүзден бесі) it can be 88.05 or 88 and 05, жетіләнші-жетінші -seventh, онләнші-оныншы-tenth.

The vocabulary of the Kazakh language of the people living in the south of Karakalpakstan is characterized by a great number of professionalisms dealing with cattle breeding, fishing, cereals, ricegrowing, cotton-growing, gardening and farming.

Thus, we see that the people living in this part of Karakalpakstan speak in Kazakh and their vocabulary was developed and enriched under the influence of the Uzbek, Karakalpak and Turkmenian languages. The vocabulary stock of this Kazakh language includes the words of the languages of the neighbouring countries.

\section{REFERENCE}

1. Karimov I.A. Turkiston - our common house. Tashkent, 1995.

2. Abdullaev F. Khorezm dialects. Tashkent, 1961. $346 p$.

3. Berdimuratov E. Lexicology of the modern Karakalpak language. Nukus, 1994.

4. Bekmuratova G. Shomanai dialect of the Karakalpak language. Nukus: Bilim, 2004.

5. Nurmagambetov A. The Kazakh language in Turkmenistan.1974.230 p.

6. Omarbekov S. The study of the Kazakh language by the linguistic geographical method. State language and culture of spirituality. Alma-Ata, 2001. 